\title{
Methane dynamics in a seasonally hypoxic coastal marine basin
}

\author{
OLGA M. ZYGADLOWSKA ${ }^{1}$, WYTZE K. LENSTRA ${ }^{1}$, \\ NIELS A.G.M. VAN HELMOND ${ }^{1}$, THOMAS RÖCKMANN ${ }^{1}$, \\ JESSICA VENETZ ${ }^{2}$, ANNA J. WALLENIUS ${ }^{2}$, PAULA \\ DALCIN MARTINS ${ }^{2}$, ANNELIES J. VERAART ${ }^{2}$, MIKE S. M. \\ JETTEN $^{2}$ AND CAROLINE P. SLOMP ${ }^{1}$ \\ ${ }^{1}$ Utrecht University \\ ${ }^{2}$ Radboud University \\ Presenting Author: o.m.zygadlowska@uu.nl
}

Methane $\left(\mathrm{CH}_{4}\right)$ is a key greenhouse gas. Coastal areas account for a major proportion of marine $\mathrm{CH}_{4}$ emissions. Eutrophication and associated bottom water hypoxia enhance $\mathrm{CH}_{4}$ production in coastal sediments worldwide. This can lead to a shoaling of the sulfate methane transition zone (SMTZ) in the sediment, less efficient anaerobic $\mathrm{CH}_{4}$ oxidation and increased escape of $\mathrm{CH}_{4}$ to the overlying water. The pathways of microbial $\mathrm{CH}_{4}$ removal in the sediment and water column of such coastal systems are still not well explored.

In this study, we assess the fate of $\mathrm{CH}_{4}$ produced in coastal sediments at a site in a seasonally hypoxic coastal marine basin (Scharendijke, Lake Grevelingen, the Netherlands) in March and September 2020. The site is characterized by high rates of sediment $\mathrm{CH}_{4}$ production and a shallow SMTZ $(\sim 5-10 \mathrm{~cm}$ depth). We find that, in March, when the water column is fully oxygenated, most $\mathrm{CH}_{4}$ produced is removed in the sediment through anaerobic and aerobic oxidation pathways. When waters below $35 \mathrm{~m}$ depth are anoxic and sulfidic, as observed in September, the SMTZ in the sediment shoals further and substantial $\mathrm{CH}_{4}$ escapes from the sediment and accumulates below the redoxcline. Methane isotope profiles $\left(\delta^{13} \mathrm{C}-\mathrm{CH}_{4}, \delta \mathrm{D}\right.$ $\mathrm{CH}_{4}$ ) indicate limited removal of $\mathrm{CH}_{4}$ in the sediment and in the anoxic part of the water column in September. Most $\mathrm{CH}_{4}$ removal takes place at the redoxcline, likely through aerobic oxidation. Elevated $\mathrm{CH}_{4}$ concentrations in near-surface waters $(140 \mathrm{nM})$ point towards potential release of $\mathrm{CH}_{4}$ to the atmosphere in this coastal area. 